\title{
14
}

\section{Down Payments on National Environmental Accounts}

\author{
Michael Vardon, John Ovington, Valdis Juskevics, \\ John Purcell and Mark Eigenraam
}

\section{Key Points}

- Environmental accounting is promoted in Australia and around the world as a way of providing regular information on changes in the state of the environment to support policy development and decision-making.

- In Australia, significant progress on the development and implementation of environmental accounting has been made at different levels of government, academia, corporations and nongovernment organisations. This includes the production of accounts for mineral and timber assets, water, waste, land and ecosystems.

- Australia's efforts represent a significant down payment on national environmental accounting. Standards have been recommended and a range of agencies have experience in the production of the accounts.

- However, there is a lack of knowledge of environmental accounting at senior levels of government, and how it can be applied to mainstream policy-and decision-making, and this is a major barrier.

- Attaining the resources and institutional arrangements needed to regularly produce accounts and use them in decision-making processes will require a greater focus on meeting the needs of decision-makers. 
- In memory of Dr Rob Lesslie, his contributions to the development of environmental accounting, and land accounts in particular, are highlighted.

\section{Introduction}

Environmental accounting in Australia has been advanced by many organisations, including national and state government agencies, regional natural resource management (NRM) authorities, and business and non-government organisations. In addition, there has been a range of closely related activity on the development of information systems and clarification of concepts that are measured and reported in the accounts, such as ecosystem services and environmental condition.

A call for the development of environmental accounts has been made in several government documents relating to the environment (see Hawke, 2009; Morton \& Tinney, 2011); it featured in a former government's vision of Australia in the Asian Century (Commonwealth of Australia, 2012) and is a specific focus of the National Plan for Environmental Information Initiative (Department of Environment and Energy [DEE], n.d.-a). Yet, despite these calls, progress has been limited. Key barriers to the development and use of environmental accounting have been (and remain) a lack of understanding about what environmental accounting is, and how environmental accounts can inform policies, programs and decisions.

\section{What is Environmental Accounting?}

At its simplest, environmental accounting is a way of organising information. It is based on a model of stocks and flows and the measurement of transactions between parties (e.g. a buyer and seller). For example, someone buying a bag of apples from a market exchanges money: $\$ 5$ for a 4-kilogram bag. The buyer's stock of apples goes from 0 to 4 kilograms, while their stock of money goes down. If they had $\$ 100$, the buyer's remaining stock of money would be $\$ 95$. Meanwhile, the seller's stock of apples is reduced by 4 kilograms, and their stock of money is increased by $\$ 5$. This type of accounting allows businesses to 
manage inventories, cash flows and assets. Business accounting of this type has been around for centuries and was formalised by Pacioli in 1496 (Gleeson-White, 2014).

National accounting for the purposes of managing entire economies, and not just business or government finances, evolved in the twentieth century. It grew out of the need to better manage the economy during the Great Depression and World War II (Obst \& Vardon, 2014). Recognised shortcomings in the treatment of the environment in the national accounts eventually led to the creation of the System of EnvironmentalEconomic Accounting (SEEA), which provides a means of recording the transactions between the environment and the economy. The SEEA was adopted by the United Nations (UN) as an international standard in 2012 (UN, 2014a) ${ }^{1}$ and extended to cover ecosystem accounting in 2013 (UN, 2014b). ${ }^{2}$

The SEEA provides a system for integrating environmental information across domains (e.g. water, energy, pollution and biodiversity) with economic information. Physical information on the environment can be compared with economic transactions to help identify areas (e.g. coastal areas) or industries (e.g, agricultural) for particular attention based on the impact they are having on the environment, as well as the risk to economic activity from environmental change.

A common misconception of environmental accounting is that its aim is to measure and value everything in monetary terms. While it is true that the scope of environmental accounts includes both physical and monetary measures, these can be produced separately. Indeed, many accounts (and most of those produced so far in Australia) only include physical measures, as discussed below.

Environmental accounting has many potential applications. An independent review of the Environmental Protection and Biodiversity Conservation Act 1999 (Hawke, 2009) listed numerous expected benefits from the production of regular environmental accounts, including:

1 The SEEA Central Framework was adopted at the 2012 meeting of the UN Statistics Commission; however, the final version was not published until 2014.

2 The SEEA Experimental Ecosystem Accounting was recognised at the 2013 meeting of the UN Statistics Commission; however, the final version was not published until 2014. 
- providing measurable ways of comparing and assessing environmental assets over time

- providing a practical base for investing in future actions for environmental assets

- providing information to underpin evidence-based decision-making

- better targeting of private and public investment at the program and project level

- better measurement and understanding of the impacts and effectiveness of policies and investments

- allowing for better identification and management of risks

- providing greater community visibility on environmental outcomes

- guiding environmental and land use planning, including through environmental impact assessments and regional planning

- identifying and addressing gaps in reporting requirements and informing the State of the Environment reporting process.

Applications and uses of environmental accounting around the world have been summarised by Smith (2014) and the European Commission (2014). Use of water accounts in Australia were highlighted by Vardon, Lenzen, Peevor and Creaser (2007). The uses identified ranged from sophisticated input-output, or computable general equilibrium modelling, to the identification of trends in resource use, and a comparison of these to changes in the size of the economy or population (i.e. the so-called decoupling indicators). The application of accounts to real-world management and policy is an area in need of more detailed exploration (Vardon, Burnett \& Dovers, 2016).

\section{Environmental Accounting in Australia}

An overview of environmental accounting in Australia is summarised in Figure 14.1. The Australian Bureau of Statistics (ABS) has been involved in the development of environmental accounting for over two decades and has produced the largest number of accounts. 


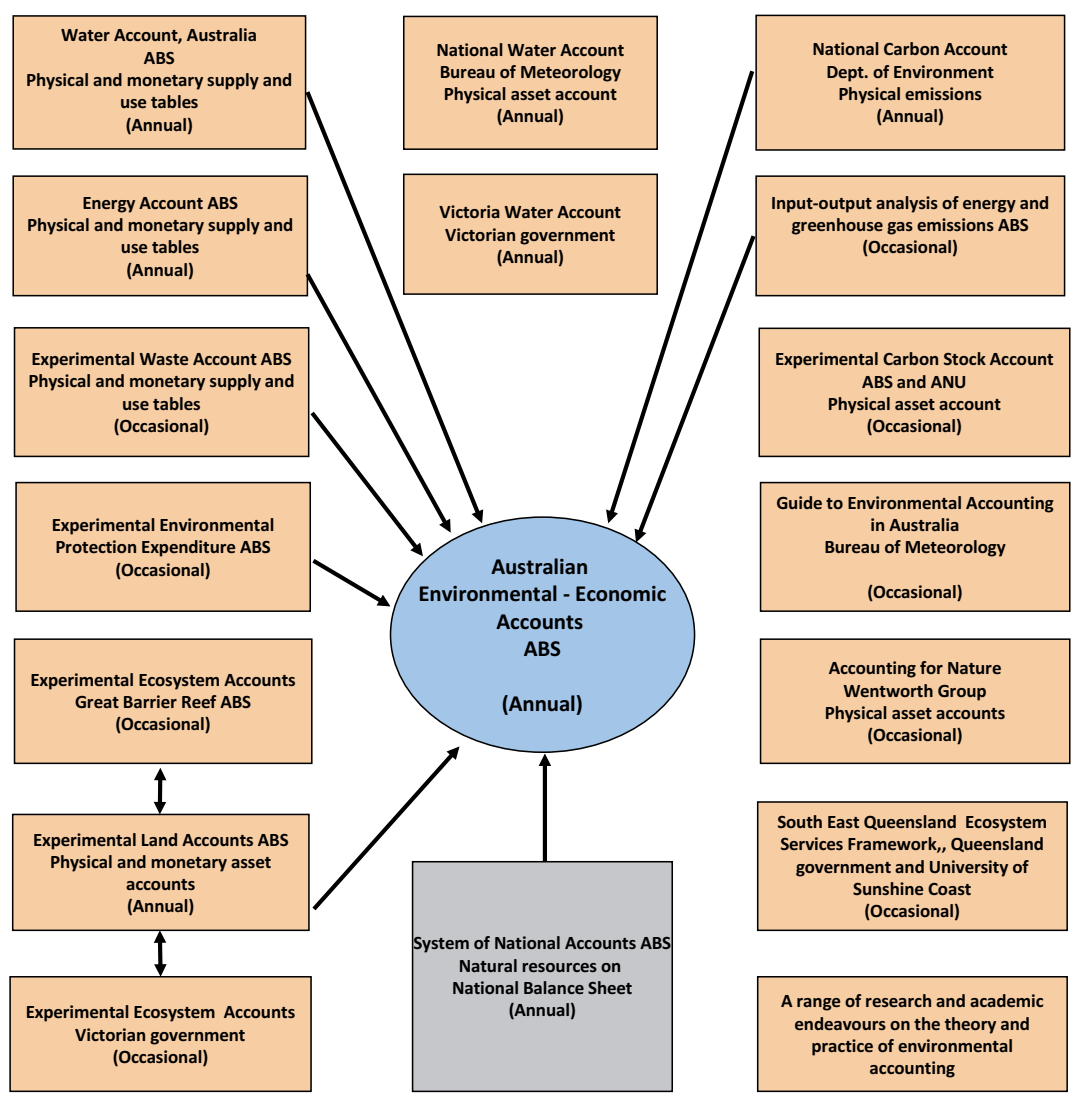

Figure 14.1: Overview of environmental accounting in Australia.

Source: Australian Bureau of Statistics. Used with permission.

Table 14.1 provides further details of the ABS accounts, including the year first published, time series available and coverage in terms of stocks and flows and monetary and physical measures. The Australian EnvironmentalEconomic Accounts (AEEA) draws together all ABS accounts; the second edition was published in 2015 (ABS, 2015a). Other major environmental accounting activity by government include the National Greenhouse Gas and Energy Reporting (DEE, n.d.-b) and the National Water Account (Bureau of Meteorology [BoM], 2014). All accounts have improved over time with better understanding of the data used in the compilation of accounts, identification of additional data, collection of new data and improvements in the systems and processes used to produce accounts. 
LAND USE IN AUSTRALIA

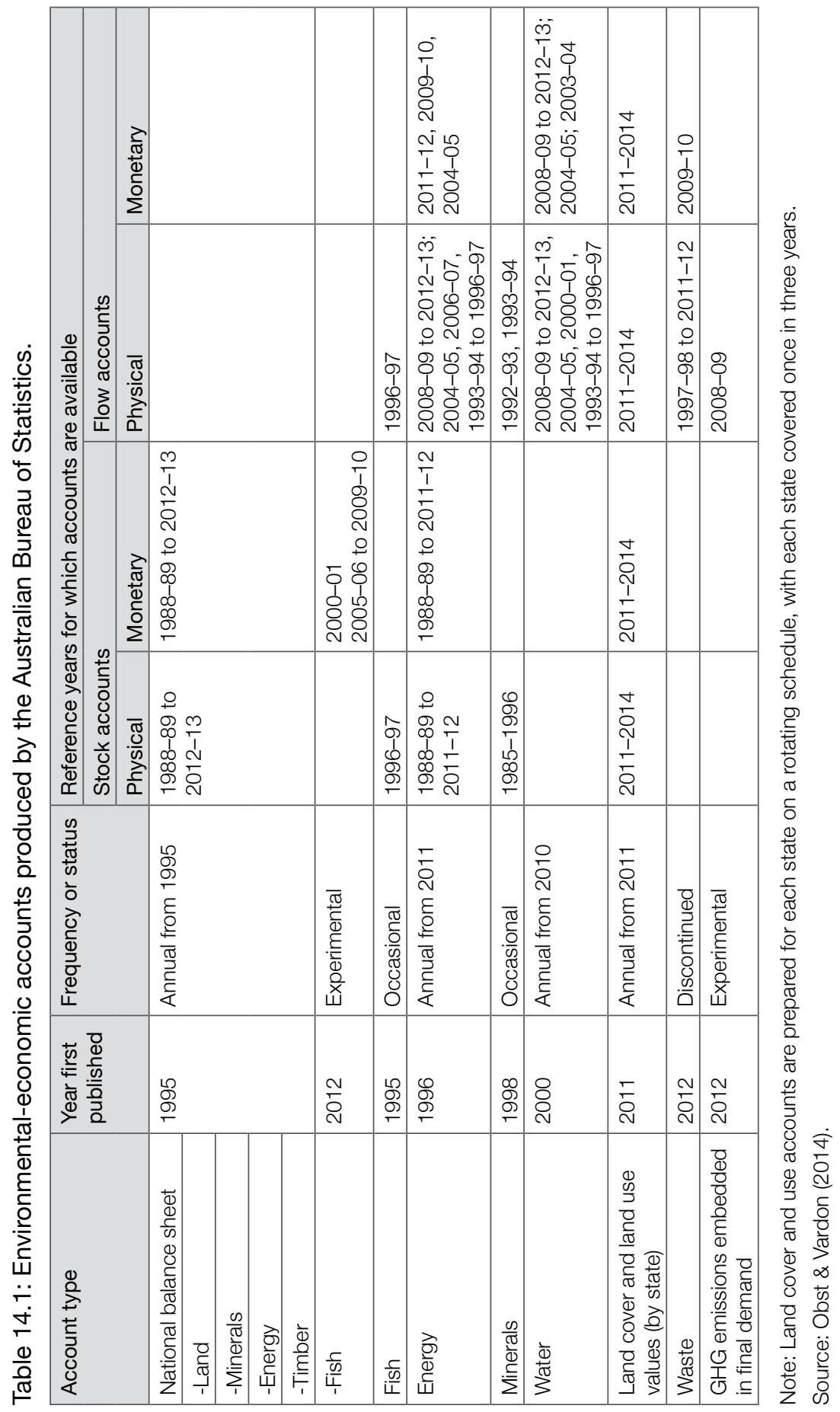


Many academics have been involved in research relating to ecosystem accounting (e.g. Aisbett \& Kragt, 2010; Binning, Cork, Parry \& Shelton, 2001; Crossman et al., 2013; Gillespie, Dumsday \& Bennett, 2008; Pittock, Cork \& Maynard, 2012; Russell-Smith et al., 2013; Stoeckl et al., 2011; Straton \& Zander, 2009; Tovey, 2008; van Dijk et al., 2014). This activity has added significantly to the theory and practice of environmental accounting in Australia.

Different initiatives have focused on various aspects of the accounts in terms of concepts, themes or metrics. For example, ecosystem service flows were the focus of the Department of Environment, Water, Heritage and Arts (2009); Maynard, James and Davidson (2010); and Cork et al. (2012). However, the condition of ecosystems assets was the focus of the Wentworth Group of Concerned Scientists (2008, 2013; Sbrocchi 2015). The ABS (see Table 14.1) compiled accounts in both monetary and physical metrics for land, water, waste and energy using information on stocks and flows; by contrast, water (in physical terms) has been the main focus of the BoM.

There has been some confusion about the water accounts published by the ABS and BoM. It is important to recognise that water accounting involves a series of accounts; the SEEA-Water describes 12 different types of standard accounts (UN, 2012)-less than half of which have been produced for Australia. The main differences are that the ABS Water Account, produced since 2000, explicitly follows the SEEA and is composed of physical and monetary supply use tables. The BoM National Water Account, produced since 2007, is primarily an asset account in physical terms. The BoM account follows standards developed by the Water Accounting Standards Board and does not explicitly use the SEEA, although it can be mapped into the SEEA (Vardon, 2012).

The ABS and BoM have also worked closely together on the development of accounting frameworks. In 2013, the BoM recommended the adoption of the SEEA (BoM, 2013). Together, these two agencies coordinated the Australian inputs to the drafting of the System of EnvironmentalEconomic Accounting - Experimental Ecosystem Accounting (SEEAEEA) (UN, 2014b). As an example of this coordination, in May 2012, the ABS, BoM and Victorian Department of Sustainability and Environment hosted an Expert Meeting on Ecosystem Accounts (2012) as part of the SEEA-EEA development. 
There have also been environmental accounting initiatives by the corporate sector. Business accounting for the environment has proceeded along a variety of fronts (see Gleeson-White, 2014). This type of accounting is concerned with the management of individual businesses, rather than the environment or economy as a whole. While the basic principles of this type of accounting are similar, and much can be learned from the approaches used by businesses-in particular, how accounts are used in management-it is not given further consideration here, as the focus is on national environmental accounts.

\section{Land Accounting}

This section examines the development of land accounting in Australia. The reason for the focus on the development of these types of accounts is fourfold:

1. Land accounting is the foundation of ecosystem accounting, which is at the leading edge of accounting nationally and internationally.

2. Land accounting provides a good example of the theoretical and practical development of information sources and accounts in Australia.

3. There are existing summaries of water (see Godfrey \& Chalmers, 2012) and greenhouse gas reporting (see DEE, n.d.-c), which are the other accounts in regular production.

4. In memory of Rob Lesslie, who was involved in the development of land accounts from the beginning.

Rob Lesslie was a key contributor to land accounting in the early stages of methodological development and provided vital support and encouragement to the ABS and others involved. He also provided a link to earlier work on land information (e.g. National Land and Water Resources Audit) and important input to measuring vegetation condition at large scales via the development of the vegetation assets, states and transitions (VAST) framework (Thackway \& Lesslie, 2006).

The key to the integration of environmental and economic information via accounts is spatially explicit data. This can be illustrated by the development of integrated environmental-economic accounts for land by the ABS. This has been prepared for several states (i.e. Victoria, South Australia and New South Wales [NSW]), the Great Barrier Reef Region and the Murray-Darling Basin. The Great Barrier Reef is an area of 
international significance; it is listed on the UN Educational, Scientific, Cultural Organization's World Heritage List. The Murray-Darling Basin is an important agricultural area that is under increasing environmental and economic pressure from the limited availability of water, which is exacerbated by droughts. The focus here is on the Great Barrier Reef, for which both land and ecosystem accounts have been completed (ABS, 2011, 2014b, 2015b).

In February 2011, the ABS released the first experimental land accounts for the Great Barrier Reef region. These accounts were the culmination of seven years of investigative work; they were followed by a second set of land accounts (ABS, 2014b) and ecosystem accounts (ABS, 2015b). The accounting work grew out of surveys of land management practices that were initially conducted in NSW and Queensland. The surveys were published as:

- Eurobodalla (NSW) (ABS, 2005)

- Fitzroy and Livingstone Shires (Queensland) (ABS, 2006)

- Great Barrier Reef catchments (Queensland) (ABS, 2010).

These surveys embodied several innovations. In Eurobodalla, the land parcel, comprising a defined spatial area, was used as the statistical unit of observation, rather than the traditional business unit (i.e. the farm business). The use of a land parcel as the statistical unit provided the opportunity to explicitly link the biophysical information available (e.g. from remote sensing) to the management practices on the land parcel and other administrative data. The initial work identified several areas for methodological improvement; it also revealed opportunities, such as how other information sources could be incorporated into the approach.

The studies of the Fitzroy and Livingstone Shires developed a new approach for collecting land-based data. The survey design was based on the cadastre (land boundaries based on ownership). This was combined with administrative data held by state and local governments, enabling a random selection of land parcels of agricultural land to which ownership details could be attached. The survey was the first to use forms tailored to each selected business. Each survey included a map that showed every cadastral parcel owned by that business; owners were asked to provide information for the selected parcels only. An unintended but important and welcome outcome of this strategy was that it encouraged landowners to become more engaged with the survey, resulting in improved response rates and improved data quality. 
The flexibility of using a spatial unit as the primary statistical unit was apparent in the information presented for the Fitzroy and Livingstone Shires (ABS, 2005). In this, the data could be aggregated to different geographies: by shire, the riparian zone of the Fitzroy River, the coastal zone, by radial zones from the Rockhampton City Centre and by 23 neighbourhood catchments. In a traditional business survey approach, only one set of geographical boundaries would have been possible (i.e. by shire).

The 2009 survey of land management practices of the Great Barrier Reef catchments further refined the land parcel methodology. Conducted under the auspices of the Australian Government's Reef Rescue initiative, it provided information on the land management practices affecting the amount of sediment reaching the Great Barrier Reef. Financial support was provided via the Caring for our Country initiative. Other support came from the Queensland Government via the Department of Environment and Resource Management, and from the office of the Valuer-General, which provided access to cadastral data.

This work led to the publication of the first experimental land accounts (ABS, 2011). These accounts presented information on land use, land cover and the value of land. They included data from a wide range of sources, such as the:

- Public Sector Mapping Agency (for the provision of the Cadlite ${ }^{\circledast}$ and Transport and TopographyTM)

- BoM (climate data)

- Geoscience Australia and the Australian Bureau of Agricultural and Resource Economics (dynamic land cover mapping)

- Department of Climate Change and Energy Efficiency (forest extent and change)

- Australian Bureau of Agricultural and Resource Economics (catchmentscale land use of Australia)

- North Australian Fire Information (fire frequency data)

- Department of Environment and Resource Management (land use classifications and land values for land parcels; data on wetlands)

- Department of Sustainability, Environment, Water, Population and Communities (wetlands data). 
Land accounts for the Great Barrier Reef region were compiled and published by the ABS in 2014. Again, a wide variety of data sources were used; however, in this case, the ABS collected no additional data (i.e. the information presented was compiled from existing data sources within and outside the $\mathrm{ABS}$ ). The production of the second set of accounts was important, as it demonstrated that repeat production was possible. It also meant that changes between the two time periods could be presented (see Figures 14.2a and 14.2b).

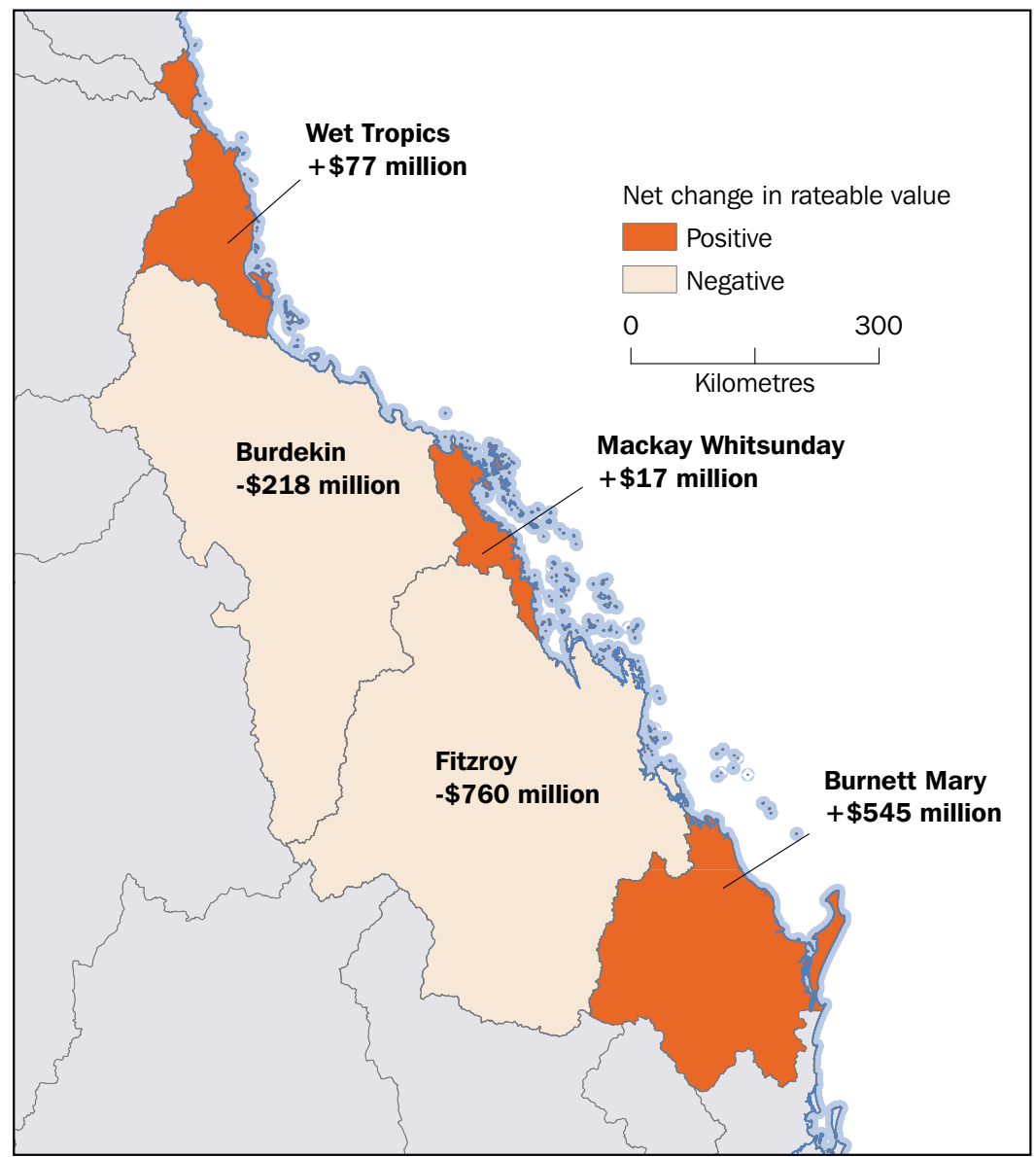

Figure 14.2a: Net change in rateable value of land used for livestock grazing between 2009 and 2013.

Source: ABS (2014a). 


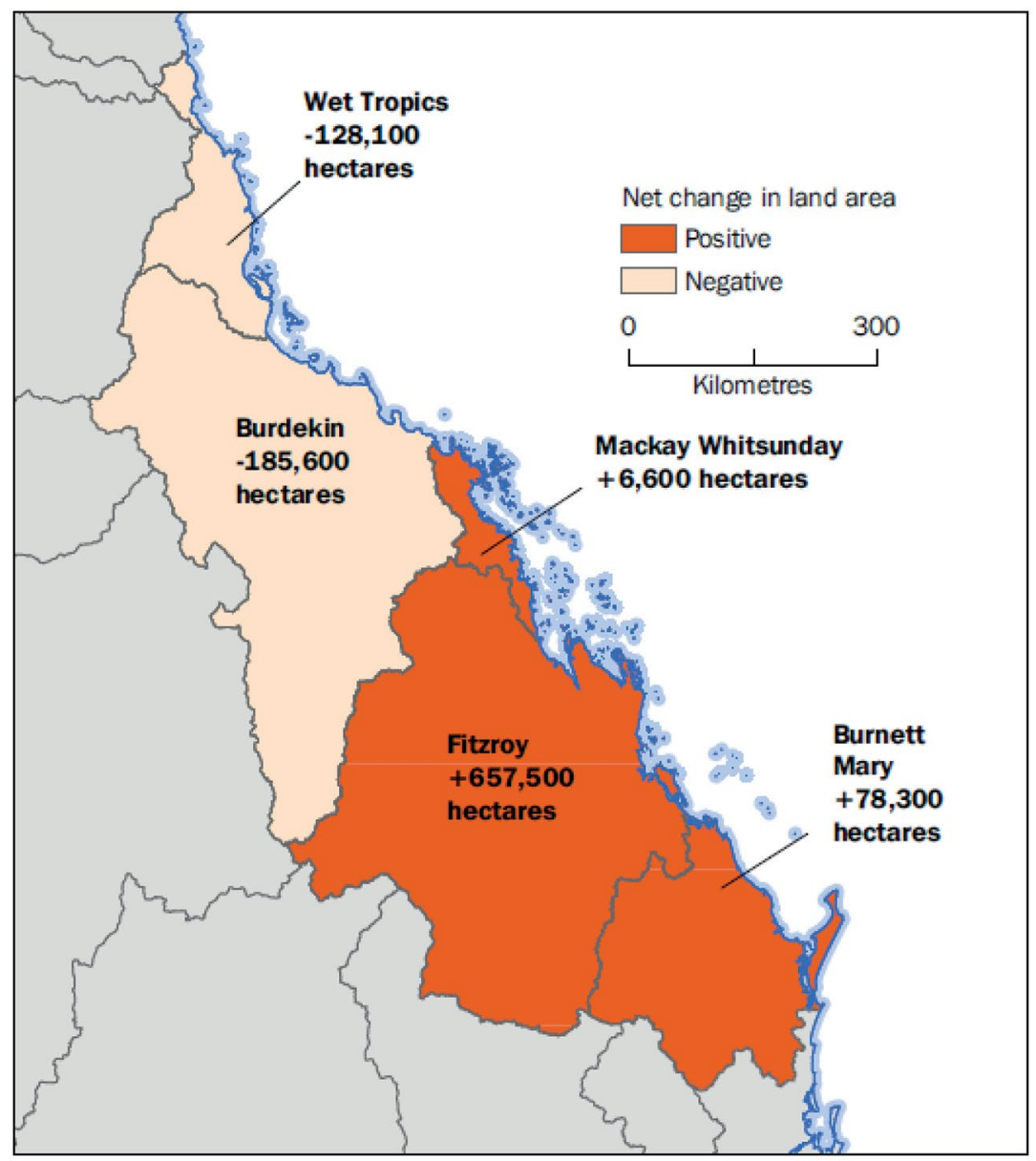

Figure 14.2b: Net change in land used for grazing 2009-13.

Source: Compiled from existing data sources within and outside the Australian Bureau of Statistics.

Land accounting is now part of the regular production of environmental accounts by the ABS. A land cover account based on dynamic land cover data is produced annually as part of the AEEA, while the total value of land is recorded on the national balance sheet. State land use accounts are scheduled to be produced every three years. So far, land accounts have been produced for Victoria (in 2012) and Queensland (ABS, 2013). 


\section{Ecosystem Accounting}

Ecosystem accounting, focusing on the role of natural capital and its ecosystem services, has been an area of interest in Australia for more than a decade (e.g. Aisbett \& Kragt, 2010; Binning et al., 2001; Crossman et al., 2013; Gillespie et al., 2008; Pittock et al., 2012; RussellSmith et al., 2013; Straton \&Zander, 2009; Tovey, 2008). The independent think tank Australia21 prepared a discussion paper on ecosystem services for the Department of Agriculture, Fisheries and Forestry that examined the literature relating to ecosystem services from Australia and around the world (Cork et al., 2012). The paper considered how ecosystem services could contribute to policy and management in relation to natural resources and human wellbeing in Australia. It concluded that there are issues to be addressed in relation to how an ecosystem services approach might be put into practice. At the time, a range of additional activity was in progress; since then, examples of how the concepts of ecosystem services and natural capital can be put into practice have emerged. These are summarised below.

\section{Victoria}

The Victorian Government was the first in Australia to produce ecosystem accounts (see Eigenraam, Chua \& Hasker, 2013). They were linked directly to the ABS land accounts (ABS, 2012a) and used the same spatial output regions. Victoria is an interesting example because its accounts evolved along with the administrative processes that both used and populated the accounts. Further, they grew out of market-based schemes designed to promote the retention or regeneration of native vegetation on private land (see Stoneham, O’Keefe, Eigenraam \& Bain, 2012).

The Victorian ecosystem accounts show changes in native vegetation area and condition by type of native vegetation between 1750 and 2005 (see Table 14.2). Similar tables are available for each NRM region, bioregion and statistical area. The level of change varied between vegetation types; eucalypt woodlands suffered the largest absolute fall in area (nearly 6 million hectares), while callitris forests, woodlands and tussock grasslands shared the largest fall in condition, from 1.00 to 0.33 habitat hectares (along with a large percentage of change in terms of area). 
Table 14.2: Victorian terrestrial extent and condition classified by major vegetation groups: 1750 and 2005.

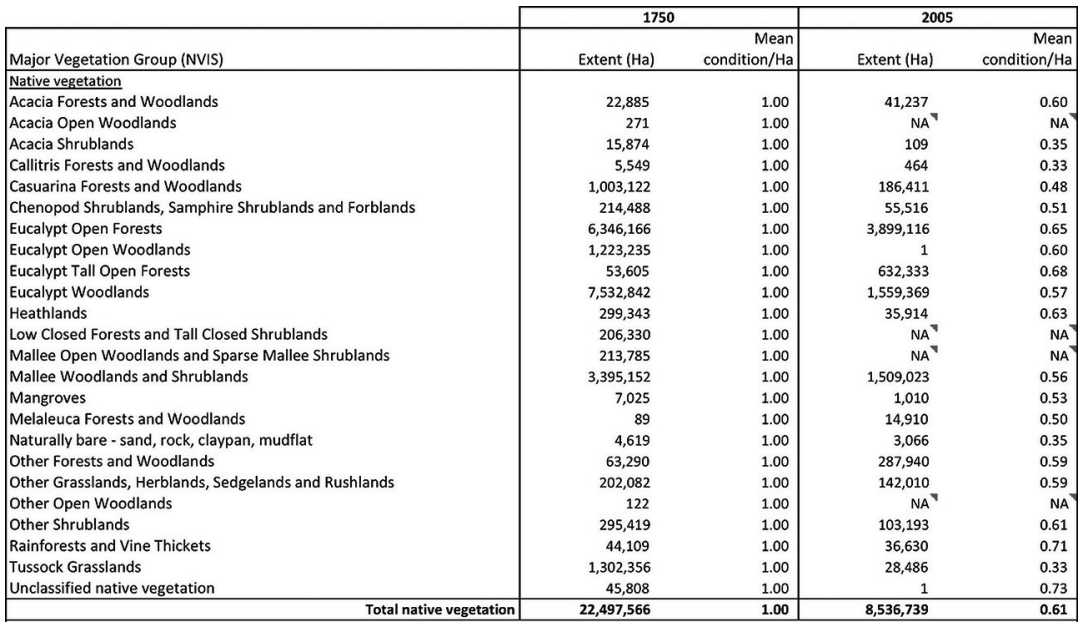

Source: Eigenraam et al. (2013, Table 1.1.0).

This account can be used to target particular vegetation types for attention in terms of either extent or quality, as well as the services they provide, including habitat for rare and threatened species. The accounts allow for structured comparisons within and between the regions and vegetation types in both absolute and relative terms (e.g. conversion to a percentage). The linking of these accounts to the economic activity by land use accounts highlights both the drivers of change and the benefits derived from change (e.g. agriculture, forestry, rural residential, etc.).

The quantification of both the area and environmental benefits resulting from government investments on private land (i.e. value for money)as well as the cost of increasing these benefits-is a clear benefit of the accounts. For example, the result of one scheme in West Gippsland showed that for the $\$ 2.4$ million invested, government achieved an extra 1,263 hectares of private land for conservation use, which represented an average cost of $\$ 380$ per hectare per year (Eigenraam et al., 2013).

Part of the accounting done in Victoria involved quantifying the benefits expected in the future, and accounting for them now. An Environment Benefit Index (EBI) was calculated for all agricultural land in West Gippsland for 2010; the expected EBI was calculated for the same land in 2015. The flow of environmental benefits was expected to increase by 13 per cent, from $\$ 271$ million to $\$ 307$ million EBI (on the land 
under contract in the market-based scheme), directly due to the money invested by government in landholders. This was a very useful aspect of the accounts for managers and politicians keen to show the benefits of their decisions.

\section{South East Queensland}

The South East Queensland (SEQ) Ecosystem Services Project is a collaborative project between SEQ Catchments, the Queensland Government's Department of Infrastructure and Planning (now the Department of State Development, Infrastructure and Planning) and the University of the Sunshine Coast. The main aims of the project were to develop a framework for assessing the ecosystem services derived from the SEQ region and incorporate this information into NRM policy and planning. Several publications have resulted from the work Maynard, James \& Davidson, 2010, 2012; Petter et al., 2013).

The project was funded by the Australian Government's Caring for our Country initiative; the Queensland Departments of Environment and Heritage Protection and State Development, Infrastructure and Planning; the University of Queensland; and the Brisbane city, Moreton Bay and Redland local governments. Technical support was provided by the University of the Sunshine Coast and the Brisbane Regional Environment Council.

The work has focused on identifying, measuring and valuing ecosystem services derived from SEQ. The framework describes four components:

- ecosystem reporting categories

- ecosystem functions

- ecosystem services

- constituents of wellbeing.

A list of the data used in the assessment is available from the project's website; ${ }^{3}$ the data layers that were used are also available. ${ }^{4}$ The framework recognises that ecosystems contribute to human wellbeing (through the delivery of ecosystem services) and that human wellbeing, which is also derived through social and economic factors, effects the use and condition

3 See www.ecosystemservicesseq.com.au/LiteratureRetrieve.aspx?ID=125963

4 See www.ecosystemservicesseq.com.au/LiteratureRetrieve.aspx?ID=120350 
of ecosystems. While the SEQ framework does not explicitly use the SEEA or accounting, the aims of the project suggest that accounting could play a role in the future.

\section{Wentworth Group and Condition Accounting for National Resource Management}

The Wentworth Group of Concerned Scientists has been advocating the use of environmental accounting since at least 2008 when it published Accounting for Nature. Since then, a range of work has been undertaken at both theoretical and practical levels. In the theoretical domain, the Wentworth Group has focused on the development of a metric or 'common currency', which it calls the Environmental Condition Index (Econd).

Econd is not a monetary value; its intent is to allow for the comparison of relative conditions of different environmental assets (e.g. a river with a forest) in different locations, using different metrics. Econd uses the science of reference benchmarking to create an index between zero and 100 that compares the current condition of an asset against a scientific estimate of its natural or potential condition in the absence of significant human alteration.

With funding from a variety of sources, and with support from experts in Australian and state government agencies, the Commonwealth Scientific and Industrial Research Organisation (CSIRO) and the Ian Potter Foundation, the Wentworth Group has undertaken a regional-scale trial of the Accounting for Nature model. The group's ultimate objective is to aggregate this information to create national environmental asset condition accounts. Ten of Australia's 54 regional NRM authorities are involved.

These trials are not yet complete; however, preliminary information is available (Wentworth Group, 2013; Sbrocchi, 2015). The trials have demonstrated that it is practical to apply the concept of asset condition accounting. While the Wentworth Group acknowledges the SEEA, it has not attempted to map its model into the SEEA. In the future, the data that underpin the Econd could be used for accounting for ecosystem extent and condition in the SEEA. 


\section{The Great Barrier Reef}

The development of land accounts for the Great Barrier Reef region by the $A B S$ led to the production of ecosystem accounts for the region that were published in an information paper (ABS, 2015b). These accounts are consistent with the SEEA-EEA (UN, 2014b). The information paper aimed to test the application of the concepts described in SEEAEEA, and connect the scientific work undertaken in the region to other environmental and macro-economic indicator accounts compiled by the ABS that build on previous knowledge and data. The ABS accounts, which focus on agriculture, tourism, fishing and aquaculture businesses and their connection to ecosystem services and natural capital, show that it is technically possible to use existing data to create accounts.

\section{Conclusions and Recommendations}

Over two decades of work has gone into the development of environmental accounts in Australia. Australia has played a prominent role in the development and testing of the SEEA, which is now recommended for use in Australia (BoM, 2013). However, to date, the systematic and ongoing production of accounts is limited to energy and natural resources accounts (on the national balance sheet) conducted by the ABS, greenhouse gas emissions accounts conducted by the Department of Environment, and water accounts conducted by the ABS and BoM. Despite this, the ongoing development of environmental information systems, combined with increased understandings of the concepts and practices of environmental accounting, means that Australia is well placed to produce accounts when demand grows and the necessary resources are allocated.

Strong partnerships have been a factor in the development of environmental accounting in Australia. These partnerships are required between professions and agencies. Those working together, or at least sharing knowledge and experiences, include the $\mathrm{ABS}$ and $\mathrm{BoM}$; the Australian government department responsible for climate change and the environment; the Victorian, Queensland and South Australian state governments; and CSIRO. Various academic institutions and nongovernment organisations are also involved, such as The Australian National University, University of Queensland, University of Melbourne, University of Sydney and the Wentworth Group of Concerned Scientists. 
These partnerships, which encompass a range of professions and specialisations, see geographic information professionals working handin-hand with accountants, economists, scientists, statisticians and others.

The production of environmental accounts has improved over time. This is due to greater familiarity with the concept of accounting, as well as refinements in the design of data-compilation activities. Much of the work has involved 'learning by doing', which allows the development of the accounts to be a collaborative process. Repeated production of accounts leads to increased quality. It also allows for efficiencies in compilation processes to be gained through:

- increased knowledge and skills of staff

- ongoing development and use of information technology to support production

- provision of feedback to primary data sources and subsequent improvement in the quality of the primary data

- filling data gaps and deficiencies through the identification or creation of new data sources

- development of useful indicators from the accounts and other data (e.g. gross value of irrigated production per megalitre of water).

The regular production of accounts allows them to be built into policy development, monitoring and evaluation processes.

The value of environmental accounts will be fully realised when they are used in the mainstream decision-making processes of governments, companies and economic activities. Generally, environmental accounts are poorly understood by potential users. Demonstrating how environmental accounts may be applied to policy is a vital first task. In this, the communication of the accounts needs to recognise and target different audiences-policymakers, scientists, economists, accountants, statisticians - and understand the different world views and motivations for accounts. Spatially explicit environmental accounting provides new opportunities for deeper insight and more sophisticated analysis that goes well beyond traditional tabular presentations of accounting data and key summary indicators. 


\section{References}

Aisbett, E. \& Kragt, M. (2010). Valuing ecosystem services to agricultural production to inform policy design (Research Report No. 73). Retrieved from crawford.anu.edu.au/research_units/eerh/pdf/EERH_RR73.pdf

ABS (Australian Bureau of Statistics). (2005). Land management: Eurobodalla shire, NSW, 2003-04 (Catalogue No. 4651.0). Retrieved from www.abs.gov.au/AUSSTATS/abs@.nsf/allprimarymainfeatures/ 18CAF66FC2574C15CA25710700781E82?opendocument

ABS. (2006). Land management: Fitzroy and Livingstone shires, Queensland, 2004-05 (Catalogue No. 4651.0). Retrieved from www.abs.gov.au/ ausstats/abs@.nsf/mf/4651.0

ABS. (2010). Land management practices in the Great Barrier Reef catchments, final (Catalogue No. 4619.0.55.001). Retrieved from www.abs.gov.au/ausstats/abs@.nsf/mf/4619.0.55.001

ABS. (2011). Land accounts, Great Barrier Reef region, experimental estimates (Catalogue No. 4609.0.55.001). Retrieved from www.abs. gov.au/AUSSTATS/abs@.nsf/allprimarymainfeatures/6FC78D6DA CEF1193CA257D18001339D2?opendocument

ABS. (2012a). Land accounts, Victoria, experimental estimates (Catalogue No.4609.0.55.002). Retrieved from www.abs.gov.au/ausstats/abs@. $\mathrm{nsf} / \mathrm{mf} / 4609.0 .55 .002$

ABS. (2012b). Completing the picture-environmental accounting in practice (Catalogue No. 4628.0.55.001). Retrieved from www.abs.gov. au/ausstats/abs@.nsf/mf/4628.0.55.001

ABS. (2013). Land accounts, Queensland, experimental estimates (Catalogue No.4609.0.55.003). Retrieved from www.abs.gov.au/ausstats/abs@. $\mathrm{nsf} / \mathrm{mf} / 4609.0 .55 .003$

ABS. (2014a). Land accounts, Great Barrier Reef region, experimental estimates (Catalogue No. 4609.0.55.001). Retrieved from www.abs. gov.au/ausstats/abs@.nsf/mf/4609.0.55.001

ABS. (2014b). Water account, Australia (Catalogue No. 4655.0). Retrieved from www.abs.gov.au/ausstats/abs@.nsf/mf/4610.0 
ABS. (2015a). Australian environmental-economic accounts (Catalogue No.4655.0). Retrieved from www.abs.gov.au/ausstats/abs@.nsf/mf/ 4655.0

ABS. (2015b). Information paper: An experimental ecosystem account for the Great Barrier Reef region (Catalogue No. 4680.0.55.001). Retrieved from www.abs.gov.au/ausstats/abs@.nsf/mf/4680.0.55.001

Binning, C., Cork, S., Parry, R. \& Shelton, D. (2001). Natural assets: An inventory of ecosystem goods and services in the Goulburn broken catchment. Canberra, ACT: CSIRO.

BoM (Bureau of Meteorology). (2013). Guide to environmental accounting in Australia. Retrieved from www.bom.gov.au/environment/docl environmental_accounting_guide.pdf

BoM. (2014). National water account. Retrieved from www.bom.gov.au/ water/nwa/

Commonwealth of Australia. (2012). Australia in the Asian century. Retrieved from www.murdoch.edu.au/ALTC-Fellowship/_document/ Resources/australia-in-the-asian-century-white-paper.pdf

Cork, S., Gorrie, G., Ampt, P., Maynard, S., Rowland, P. Oliphant, R., ... Stephens, L. (2012). Discussion paper on ecosystem services for the Department of Agriculture, Fisheries and Forestry (Final Report) [Australia21 website]. Retrieved from www.australia21.org.au/wpcontent/uploads/2013/08/ALEcosystemservicesR1.pdf

Crossman, N. D., Burkhard, B., Nedkov, S., Willemen, L., Petz, K., Palomo, I., ... Maes, J. (2013). A blueprint for mapping and modelling ecosystem services. Ecosystem Services 4, 4-14, doi.org/10.1016/j. ecoser.2013.02.001

DEE (Department of Environment and Energy). (n.d.-a). National plan for environmental information initiative. Retrieved from www.environment. gov.au/science/national-plan-environmental-information

DEE. (n.d.-b). National greenhouse gas and energy reporting. Retrieved from www.environment.gov.au/climate-change/greenhousegas-measurement/nger 
DEE. (n.d.-c). National greenhouse and energy reporting publications. Retrieved from www.environment.gov.au/climate-change/greenhousegas-measurement/publications

Department of Environment, Water, Heritage and Arts. (2009). Ecosystem services: Key concepts and applications. Retrieved from www. environment.gov.au/biodiversity/publications/ecosystem-serviceskey-concepts-and-applications

Eigenraam, M., Chua, J. \& Hasker, J. (2013). Environmentaleconomic accounting: Victorian experimental ecosystem accounts (Version 1.0) [Department of Sustainability and Environment website]. Retrieved from ensym.dse.vic.gov.au/docs/Victorian $\% 20$ Experimental\%20Ecosystem\%20Accounts,\%20March\%202013.docx

European Commission. (2014). SEEA extensions and applications. Retrieved from unstats.un.org/unsd/envaccounting/ae_white_cover.pdf

Expert Meeting on Ecosystem Accounts. (2012, 16-18 May). List of documents. Retrieved from unstats.un.org/unsd/envaccounting/seea LES/egm2/lod.htm

Gillespie, R., Dumsday, R. \& Bennett, J. (2008). Estimating the value of environmental services provided by Australian farmers. Surrey Hills, NSW: Australian Farm Institute.

Gleeson-White, J. (2014). Six capitals. Sydney, NSW: Allen \& Unwin.

Godfrey, J. M. \& Chalmers, K. (2012). Water accounting: International approaches to policy and decision-making. Cheltenham, UK: Edward Elgar. doi.org/10.4337/9781849807500

Hawke, A. (2009). The Australian Environment Act-report of the independent review of the Environment Protection and Biodiversity Conservation Act 1999 [Department of the Environment, Water, Heritage and the Arts website]. Retrieved from www.environment.gov. $\mathrm{au} /$ system/files/resources/5f3fdad6-30ba-48f7-ab17-c99e8bcc8d78/ files/final-report.pdf

Maynard, S., James, D. \& Davidson, A. (2010). The development of an ecosystem services framework for south east Queensland. Environmental Management 45(5), 881-95. Retrieved from link. springer.com/article/10.1007\%2Fs00267-010-9428-z 
Maynard, S., James, D. \& Davidson, A. (2012). An adaptive participatory approach for developing an ecosystem services framework for south east Queensland, Australia. International Journal of Biodiversity Science, Ecosystem Services and Management 7(3), 182-89. doi.org/10.1080/21 513732.2011 .652176

Morton, S. \& Tinney, T. (2011). Independent review of Australian Government environmental information activity. Retrieved from www. environment.gov.au/system/files/pages/8d3f2610-c336-4e47-aaa7f3d2b879b905/files/eia-review-discussion-paper.pdf

Obst, C. \& Vardon, M. (2014). Recording environmental assets in the national accounts. Oxford Review of Economic Policy 30, 124-44. doi.org/10.1093/oxrep/gru003

Petter, M., Mooney, S., Maynard, S., Davidson, A., Cox, M. \& Horosak, I. (2013). A methodology to map ecosystem functions to support ecosystem services assessments. Ecology and Society 18(1), 31. Retrieved from www.ecologyandsociety.org/vol18/iss 1/art31/

Pittock, J., Cork, S. \& Maynard, S. (2012). The state of the application of ecosystems services in Australia. Ecosystem Services 1, 111-20. doi.org/10.1016/j.ecoser.2012.07.010

Russell-Smith, J., Ada, J., Barker, P., Campbell, A., Cork, S., Costanza, B., ... Yates, C. (2013). Ecosystem services and livelihood opportunities for Indigenous rural communities in savanna landscapes. Retrieved from www.aceas.org.au/Ecosystem_services_and_Indigenous_livelihoodsReport.pdf

Sbrocchi, C. (2015). Australian regional environmental accounts trial: Report to NRM regions Australia. Retrieved from wentworthgroup. org/2015/03/report-to-nrm-regions-australia/2015/

Smith, R. (2014). Users and uses of environmental accounts: A review of selected developed countries. Washington, DC: World Bank. Retrieved from www.wavespartnership.org/sites/waves/files/documents/PTEC1-\%20 Users\%20and\%20Uses\%20of\%20Environmental\%20Accounts.pdf 
Stoeckl, N., Hicks, C. C., Mills, M., Fabricius, K., Esparon, M., Kroon, F., .. Costanza, R. (2011). The economic value of ecosystem services in the Great Barrier Reef: Our state of knowledge. Annals of the New York Academy of Sciences 1219, 113-33. doi.org/10.1111/j.17496632.2010.05892.x

Stoneham, G., O'Keefe, A., Eigenraam, M. \& Bain, D. (2012). Creating physical environmental asset accounts from markets for ecosystem conservation. Ecological Economics 82, 114-22. doi.org/10.1016/j. ecolecon.2012.06.017

Straton, A. \& Zander, K. (2009). The value of Australia's tropical river ecosystem services. Land and Water Australia, Tropical Rivers and Coastal Knowledge, Charles Darwin University and CSIRO, Darwin.

Thackway, R. \& Lesslie, R. (2006). Reporting vegetation condition using the vegetation assets, states and transitions (VAST) framework. Ecological Management and Restoration 7, S53-S62. doi.org/10.1111/ j.1442-8903.2006.00292.x

Tovey, J. P. (2008). Whose rights and who's right? Valuing ecosystem services in Victoria, Australia. Landscape Research 33, 197-209. doi.org/10.1080/01426390801908426

UN (United Nations). (2012). System of environmental-economic accounting for water. Retrieved from unstats.un.org/unsd/envaccounting/seeaw/ seeawaterwebversion.pdf

UN. (2014a). System of environmental-economic accounting-central framework. Retrieved from unstats.un.org/unsd/envaccounting/seea Rev/SEEA_CF_Final_en.pdf

UN. (2014b). System of environmental-economic accounting experimental ecosystem accounting. Retrieved from unstats.un.org/unsd/ envaccounting/seeaRev/eea_final_en.pdf

van Dijk, A., Mount, R., Gibbons, P., Vardon, M. \& Canadell, P. (2014). Environmental reporting and accounting in Australia: Progress, prospects and research priorities. Science of the Total Environment 473-74, 338-49 dx.doi.org/10.1016/j.scitotenv.2013.12.053 
Vardon, M. (2012). The system of environmental-economic accounting for water: Development, implementation and use. In J. M. Godfrey \& K. Chalmers (Eds.), Water accounting: International approaches to policy and decision-making (pp. 32-57). Cheltenham, UK: Edward Elgar.

Vardon, M., Burnett, P. \& Dovers, S. (2016). The accounting push and the policy pull: Balancing environment and economic decisions. Ecological Economics 124, 145-52. doi.org/10.1016/j.ecolecon.2016.01.021

Vardon, M., Lenzen M., Peevor, S. \& Creaser M. (2007). Water accounting in Australia. Ecological Economics 61(4), 650-59. doi.org/10.1016/j. ecolecon.2006.07.033

Wentworth Group of Concerned Scientists. (2008). Accounting for nature. Retrieved from wentworthgroup.org/2008/05/accounting-fornature-a-model-for-building-the-national-environmental-accountsof-australia/2008/

Wentworth Group of Concerned Scientists. (2013). Initial observations on the Australian proof of conceptregional environmental asset condition trials. Retrieved from wentworthgroup.org/2013/08/initial-observations-ofregional-environmental-accounts-proof-of-concept-trial/ 
This text is taken from Land Use in Australia: Past, Present and Future, edited by Richard Thackway, published 2018 by ANU eView, The Australian National University, Canberra, Australia.

doi.org/10.22459/LUA.02.2018.14 